\title{
DLX5 wt Allele
}

National Cancer Institute

\section{Source}

National Cancer Institute. DLX5 wt Allele. NCI Thesaurus. Code C128927.

Human DLX5 wild-type allele is located in the vicinity of 7q21.3 and is approximately $5 \mathrm{~kb}$ in length. This allele, which encodes homeobox protein DLX-5, plays a role in transcriptional activation that is essential for osteoblast differentiation. Mutation of the gene is associated with split-hand/foot malformation 1 with sensorineural hearing loss. 